九州大学学術情報リポジトリ

Kyushu University Institutional Repository

\title{
Safety Evaluation and Antimutagenic Activity of Bamboo/Wood Vinegars Collected at Different Temperatures
}

Lin, Han Chien

Laboratory of Environment Functional Materials, Department of Wood Based Materials and Design, College of Agriculture, National Chiayi University

Chen, Po-Kuang

Graduate Institute of Forest Products Science and Furniture Engineering, College of Agriculture, National Chiayi University : Master

Lai, Ying-Jang

Department of Food Science, College of Science and Engineering, National Quemoy University

Wu, She-Ching

Department of Food Science, College of Life Sciences, National Chiayi University, 他

https://doi.org/10.5109/1467647

出版情報：九州大学大学院農学研究院紀要. 59 (2)，pp. 359-368，2014-08-29. Faculty of Agriculture, Kyushu University

バージョン :

権利関係 : 


\title{
Safety Evaluation and Antimutagenic Activity of Bamboo/Wood Vinegars Collected at Different Temperatures
}

\author{
Han Chien LIN ${ }^{1 *}$, Po-Kuang CHEN ${ }^{2}$, Ying-Jang LAI $^{3}$, She-Ching WU ${ }^{4}$, \\ Gwo-Shyong HWANG ${ }^{5}$ and Noboru FUJIMOTO ${ }^{6}$
}

\author{
Laboratory of Wood Material Technology, Division of Sustainable Bioresources Science, \\ Department of Agro-environmental Sciences, Faculty of Agriculture, \\ Kyushu University, Fukuoka 812-8581, Japan \\ (Received April 30, 2014 and accepted May 12, 2014)
}

\begin{abstract}
The biological action of bamboo/wood vinegars collected at different temperatures from the exit of chimney of earthen kiln was evaluated by Salmonella mutagenesis assay, as a safety evaluation (Ames test) and reverse mutation assay (antimutagenic activity). The compounds of the vinegars were analyzed using gas chromatography-mass spectroscopy analysis. The acid, phenol and ketone compounds of bamboo vinegars were $10.65-20.09 \%, 57.87-65.98 \%$ and $10.13-18.76 \%$, and the compounds of wood vinegars were $4.27-$ $14.51 \%, 50.23-65.03 \%$ and $12.93-25.26 \%$, respectively. The vinegars' safety showed that neither cytotoxicity nor mutagenicity toward Salmonella typhimurium TA98 and TA100 with S9 mix (an external metabolic activation system) at the diluting percent content of vinegars were lower than $20.00 \%$ or less, and without the S9 mix was at $33.33 \%$ or less. The vinegars at a diluting percent content below $20.00 \%$ expressed a dose-dependent inhibitory effect against both 4-nitroquinoline- $N$-oxide (NQNO), a direct mutagen, and the mutagenicity of aflatoxin $\mathrm{B}_{1}\left(\mathrm{AFB}_{1}\right)$, an indirect mutagen which requires metabolic activation, in Salmonella typhimurium TA98 and TA100. The inhibition of the vinegars against NQNO and AFB toward $_{1}$ TA100 was better than those toward TA98. In addition, the main percent of phenol and ketone compounds in the vinegars showed cytotoxicity/mutagenicity and an antimutagenic effect against the strains mentioned above, which may partially account for the biological action of bamboo/wood vinegars.
\end{abstract}

Key words: Ames test, Antimutagenic Activity, Bamboo/Wood Vinegar, Gas Chromatography-Mass Spectroscopy, Safety Evaluation

\section{INTRODUCTION}

Both bamboo and wood vinegar, by-products of the bamboo or wood charcoal manufacturing, are brown-red transparent liquids collected during pyrolysis of bamboo or wood charcoal. Yatagai et al. (1988) reported that with the application of bamboo/wood vinegars, even the compounds are complex and different, and are mainly able to be divided into three main portions: acid, phenol and neutral compounds. The vinegars consist of 80-200 compounds: $32 \%$ organic acid, $40 \%$ phenolic compound, $3 \%$ aldehyde, 5\% alkone compound, 5\% alcohol compound, $4 \%$ ester compound and $5 \%$ others. When both are dehydrated there is usually $80 \%$ water (Ikimoto and Ikeshima,

${ }^{1}$ Laboratory of Environment Functional Materials, Department of Wood Based Materials and Design, College of Agriculture, National Chiayi University, Chiayi, Taiwan, ROC.

Master, Graduate Institute of Forest Products Science and Furniture Engineering, College of Agriculture, National Chiayi University, Chiayi, Taiwan, ROC.

Department of Food Science, College of Science and Engineering, National Quemoy University, Quemoy, Taiwan ROC.

${ }^{4}$ Department of Food Science, College of Life Sciences, National Chiayi University, Chiayi, Taiwan, ROC.

Divisions of Forest Utilization, Taiwan Forestry Research Institute (TFRI), Taipei, Taiwan, ROC.

${ }^{6}$ Laboratory of Wood Material Technology, Division of Sustainable Bioresources Science, Department of Agroenvironmental Sciences, Faculty of Agriculture, Kyushu University, Japan.

* Corresponding author (E-mail: alexhlin@mail.ncyu.edu.tw)
2000; Nomura, 2004; Uchimura et al., 2000; Tsai et al., 2009). The organic compounds in bamboo/wood vinegars may have practical applications even when present in only trace quantities (Uchimura et al., 2000; Lin et al., 2006).

Bamboo vinegar is effective in improving soil, promoting crops and preventing worm growth, as well as reducing agricultural chemicals, compost odor and sterilization (Ikimoto and Ikeshima, 2000). Recently, bamboo vinegar products have been developed that are beneficial for promoting growth of plants to as a plant root growth promoter or a $\mathrm{pH}$ value adjuster of cultural media (Huang et al., 2011; Lin et al., 2011; Ho et al., 2013). It is also effective when used against allergies (Hageta, 2004), in healthy drinks (Kobahasi, 2004; Nomura, 2004; Yoshie, 2004), as a virus/fungi/bacterial resistant (Kou, 2004; Lin et al., 2006; Lin and Shiah, 2006; Lu et al., 2007; Lin et al., 2008; Chen et al., 2010) and as an agent of antioxidation, especially for a resistant lipid oxidation effect (Tsai et al., 2009). The compounds of wood vinegar are much more complex than those of bamboo vinegar (Chen et al., 2006; Hwang et al., 2008), and can repel termites and disease germs of plants, be fungi resistant, improve the soil, promote crops or prevent worm growth and reduce the use of agricultural chemicals, such as a natural insecticide or soil fungicide (Ishihara, 1996; Nishimiya et al., 1998; Yatagai, 2002; Lu et al., 2007; Lin et al., 2009). As stated in the above references, the commercial production of bamboo/wood vinegar is being increased and highly valued for its various effective uses in Taiwan.

Horne and Paul (1996) reported that bamboo/wood 
vinegars collected at the exit of chimney of earthen or furnace kiln, when the carbonization temperature of bamboo/wood was raised to over $500^{\circ} \mathrm{C}$, produced some carcinogenic polycyclic aromatic hydrocarbons (PAHs), such as naphthalene and phenanthrene (Namiki, 1990; Vasavada and Cornforth, 2006). The concentrations of these toxics increased with the increase in temperature as well. Even though the council of agriculture in Taiwan has submitted certified agricultural standards of forest products (2004) to prove that it is necessary for bamboo/wood vinegars to be collected at $80-140^{\circ} \mathrm{C}$ at an exit of chimney of earthen kiln and below $350^{\circ} \mathrm{C}$ for a furnace kiln, collected bamboo/wood vinegars from above this range of temperatures are necessary to evaluate the potential of mutagenic and carcinogenic agents, due to the fact that both of them are omnipresent in the human environment and seem impossible to completely eliminate. Ames et al. (1975) reported that for screening of environmental mutagens and carcinogens, the Ames test (Safety evaluation), a convenient method to evaluate mutagenic activities of these chemicals, has been developed, and McCann et al. (1975) and Shugimura et al. (1976) have suggested that the mutagenic activities of a number of chemicals correlate well with the carcinogenic activities.

To expect to be one and/or a reference of functional additives for bamboo/wood vinegars, the safety evaluation, including cytotoxicity and mutagenicity, of the vinegars using the bacterial mutation assay on Salmonella typhimurium TA98 and TA100 strains with and without an extrinsic metabolic activation system were evaluated. Moreover, because the antimutagenic properties have an array of prospective applications in human care, such as the increasing application in drinks, food antioxidation, etc., and have not been reported for the antimutagenic activities of bamboo/wood vinegars that have been made so far, the antimutagenic activity of the vinegars are investigated as well. These vinegars, collected at different temperatures from the exit of earthen kiln chimney, were also investigated for their basic compound by using gas chromatography-mass spectroscopy.

\section{MATERIALS AND METHODS}

\section{Specimen preparation}

Bamboo/wood vinegars

The vinegars were collected at different temperatures, ranging from $80^{\circ} \mathrm{C}$ to $150^{\circ} \mathrm{C}$ (Uchimura et al., 2000), during the manufacturing process (pyrolysis) of charcoal from Moso bamboo (Phyllostachys heterocycla Milf) and branches/tree tops (BTW) of Cryptomeria japonica and were provided by the Division of Forest Utilization, TFRI Taipei, Taiwan (Hwang et al., 2006; Hwang et al., 2008). The bamboo and wood vinegars were based on the temperatures measured by a thermocouple at the exit of earthen kiln chimneys during bamboo/wood charcoal pyrolysis. The different groups of bamboo vinegar were collected at $80-150^{\circ} \mathrm{C}$, and with categories over 80, 90-92, 99-102, $120-123$ and $145-150^{\circ} \mathrm{C}$. The various collected temperatures of wood vinegar were $80-159^{\circ} \mathrm{C}$, and with categories 80-90, 91-100, 101-120, 121-140 and $141-159^{\circ} \mathrm{C}$. The basic properties of the bamboo/wood vinegars refer to (Lin et al., 2008; Lin et al., 2009).

Test strains

Salmonella typhimurium (S. typhimurium), including TA98 and TA100, was bought from the Bioresource Collection and Research Center, Food Industry Research and Development Institute.

Rat liver mixture

The rat liver mixture (S9 mix) (Organ Teknika Co., Switzerland) was prepared from Sprague-Dawley male rats treated with Aroclor 1254.

Mutagens

The mutagens are 4-nitroquinoline- $N$-oxide (NQNO) and aflatoxin B1 (AFB1). They were obtained from the Sigma Chemical Co. (Steinheim, Germany). All reagents used in the test were of analytical grade.

\section{Experimental methods}

Compounds analysis

Gas chromatography-mass spectroscopy (GC-MS) analysis was performed with a Varian CP-3800 chromatography instrument, combined with a Saturn-2000 mass spectrometer equipped with an electron ionization and quadrupole analyzer. The vinegars collected at different temperatures were diluted 10 times using acetone. The flow rate was set at $1.0 \mathrm{~mL} / \mathrm{min}$ and the carrier gas was nitrogen. The size of the capillary column (DB-5MS, J\&W Scientific, Folsom, CA, USA) was $30.0 \mathrm{~m} \times 250 \mu \mathrm{m}$ i.d. and its film thickness was $0.25 \mu \mathrm{m}$. The temperatures of the ion source and interface were set at $280^{\circ} \mathrm{C}$, and the mass scan range was from 40 to $550 \mathrm{amu}$. The electron energy was set at $70 \mathrm{eV}$. The oven temperature was programmed to hold at $40^{\circ} \mathrm{C}$ for $5 \mathrm{~min}$ and then, increased to $280^{\circ} \mathrm{C}$ at a rate of $12^{\circ} \mathrm{C} / \mathrm{min}$. The GC-MS chromatographic spectra of various bamboo/wood vinegar compounds were analyzed by the software of MS Workstation (Tsai et al., 2009).

\section{Ames test}

Cytotoxicity

$0.1 \mathrm{~mL}$ of bamboo/wood vinegars were diluted to a percent content of 50, 33.33, 25, 20, 13.33 and $10 \%$. The specimens were put in the test tube and mixed with $0.1 \mathrm{~mL}$ phosphate buffer saline and $0.1 \mathrm{~mL} \mathrm{S.} \mathrm{typhimu-}$ rium TA98 and TA100, and cultured overnight in nutrient broth. If there was additional S9 mix, the aforesaid addition level was changed to $0.2 \mathrm{~mL}$ phosphate buffer saline, $0.1 \mathrm{~mL}$ S. typhimurium TA98 and TA100 and cultured overnight in nutrient broth and $0.5 \mathrm{~mL}$ S9 (with S9 mix) or zero S9 (without S9 mix). Afterwards, the test tube was pre-cultured at $37^{\circ} \mathrm{C}$ for $20 \mathrm{~min}$. The mixed diluent was taken out, and then, $1 \mathrm{~mL}$ diluent was put in the plate, mixed with nutrient agar and shaken up. When the mixture solidified, the plate was placed in an incubator at $37^{\circ} \mathrm{C}$ for $48 \mathrm{~h}$. The colony (bacterial) count was calculated; if the bacterial count of the test group (including with or without S9 mix) was greater than the bacterial count of the control group by $80 \%$ (the bacterial count rate, Survival; \%), there was no toxicity (Ames and 
McCann, 1975). The survival of cytotoxicity is calculated as follows:

Survival $(\%)=($ the bacterial count of test group / the bacterial count of control group) $* 100$

Mutagenicity

The mutagenicity is analyzed by using the method proposed by Maron and Ames (1983). The test vinegars for this mutagenicity test, with or without S9 mix, are the same as for the cytotoxicity test. $0.1 \mathrm{~mL}$ phosphate buffer, $0.1 \mathrm{~mL}$ S. typhimurium TA98 and TA100 cultured overnight in oxoid nutrient broth No.2 were put into the test tube, mixed with $0.5 \mathrm{~mL}$ phosphate buffer saline and cultured at $37^{\circ} \mathrm{C}$ for $20 \mathrm{~min}$. The test mixture was mixed with $2 \mathrm{~mL}$ Molten Top Agar (including $0.05 \mathrm{mM}$ L-histidine, 0.05 Mm Biotin and 0.09 M NaCl) uniformly; the nutrient agar then was poured into the plate. When the mixture solidified, the plate was put in the incubator at $37^{\circ} \mathrm{C}$ for $48 \mathrm{~h}$, and then, the colony count was calculated. In addition, the phosphate buffer saline is only a pair of control groups (Blank). If the colony count of the TA98 and TA100 test groups is greater than that for the control group by more than two times, the specimen has mutagenicity. In other words, the Mutagenicity ratio $(\mathrm{MR})=$ induced revertants per plate/spontaneous revertants per plate (Blank).

\section{Antimutagenic activity}

The test vinegars of the antimutagenic activity were assayed according to the Ames method (Maron and Ames, 1983). The mutagens that were diluted with dimethyl sulfoxide (DMSO) were NQNO ( $1 \mu \mathrm{g} /$ plate for TA 98 and TA 100 , respectively), a direct-acting mutagen; and $\mathrm{AFB}_{1}$ ( $5 \mu \mathrm{g} /$ plate for TA 98 and TA 100, respectively), which required S9 mix for metabolic activation. A mutagen (0.1 mL; contained $1 \mu \mathrm{g}$ NQNO or $5 \mu \mathrm{g}$ AFB1) was added to the mixture of a strain (TA 98 or TA 100), and $0.1 \mathrm{~mL}$ of each test vinegar was added to the S9 mix for AFB1 or to the phosphate buffer $(0.1 \mathrm{~mol} / \mathrm{L}, \mathrm{pH} 7.4)$ for NQNO. The mutagenicity of each mutagen in the absence of an extract is defined as $100 \%$. The inhibition (\%) of mutagenicity of test vinegar is calculated as follows: Inhibition $(\%)=[1-$ (Number of his + revertants in the presence of the test vinegar - Number of spontaneous revertants)/ (Number of his ${ }^{+}$revertants in the absence of the test vinegar - Number of spontaneous revertants)] $\times 100$

\section{Statistical analysis}

The test results of the cytotoxicity, mutagenicity and antimutagenicity are represented by an average value (standard deviation), and the control group and test group are compared by Ducan's analysis. If the $\rho$ value is smaller than 0.05, meaning a significant difference between the test group and the control group, it is represented by different superscript upper case letters.

\section{RESULTS AND DISCUSSION}

\section{Compounds of bamboo/wood vinegars}

The identified compounds of bamboo/wood vinegars collected from different temperatures were analyzed with GC-MS. The acid, phenol, ketone and other compounds were found in bamboo/wood vinegars. In general, the main fraction of bamboo/wood vinegars for an acid compound is acetic acid (Yatagai et al., 1988). However, the retention time cannot be measured from the beginning point (zero) and is about $5 \mathrm{~min}$, so that the acetic acid is not shown in the results of the study. In other words, the fraction percents of compounds from bamboo/wood vinegars are calculated only from the measured compounds, shown in Tables 1 and 2.

The acid, phenol, ketone and other compounds of bamboo vinegars were 10.65-20.09\%, 57.87-65.98\%, $10.13-18.76 \%$ and 9.66-15.30, respectively (Table 1). The acid compounds included butanoic acid, 2-methoxyethyl acetate, 4-hydroxy-butanoic acid and 4-hydroxy3-methoxy-butanoic acid. The maximum fraction of acid compounds was the bamboo vinegar collected from $80-150^{\circ} \mathrm{C}$. The phenol (5.93-16.60\%), 2-methoxy-phenol (8.27-16.39\%) and 4-ethyl-phenol (3.68-9.48\%) were the main fractions of phenol compounds for bamboo vinegars. For ketone compounds, the 2-hydroxy-3-methyl-2-cyclopentenone-1-one, 2,3-dimethyl-2-cyclopentenone-1-one and maltol could be measured for bamboo vinegars collected at all temperatures. The maximum fraction of ketone compounds was the bamboo vinegar collected from $120-123^{\circ} \mathrm{C}$.

For wood vinegars (Table 2), the acid, phenol, ketone and other compounds of wood vinegars were 4.27$14.51 \%, 50.23-65.03 \%, 12.93-25.26 \%$ and $9.57-19.92 \%$, respectively. The main fractions of phenol compounds were phenol (3.36-11.30\%), 2-methoxy-phenol (11.70$22.90 \%)$ and 2-methoxy-4-methyl-phenol (7.09$20.10 \%)$. Compared to both vinegars, the maximum fraction of ketone compounds for wood vinegar was also collected at temperatures from $120-123^{\circ} \mathrm{C}$, and was higher than those for bamboo. Moreover, the range of the phenol compounds fraction for bamboo/wood vinegar was around 50-60\%; among which, the maximum fractions of phenol compounds were phenol and 2-methoxy-phenol.

\section{Cytotoxicity of bamboo/wood vinegars}

According to the former results of compound analysis, phenol, ketone and other compounds are present in bamboo/wood vinegars. Some phenol compounds displayed antimicrobial activity (Yam et al., 1997). If mutagenicity occurred in a treated material, the results of the antimutagenic assay would be affected and confused due to increased or decreased numbers of revertants of TA98 and TA100 (Duh and Yen, 1997). The phenol compounds of bamboo vinegars were $57.87-65.98 \%$, and the compounds of wood vinegars were 50.23-65.03\%. Therefore, the cytotoxicity of bamboo/wood vinegars must be determined before testing the mutagenicity and antimutagenicity of bamboo/wood vinegars. Cytotoxicity results for the bamboo/wood vinegars collected at temperatures of $90-92 / 105-109^{\circ} \mathrm{C}$ with the original vinegar (no diluting) and a range of diluting percent contents of 50.00, 33.33, 25.00, 20.00, 13.33 and $10.00 \%$ for S. typhimurium TA98 and TA100 without the S9 mix, as well as for with the S9 mix with diluting percent contents of 33.33, 
Table 1. Various Compounds of bamboo vinegars collected from different temperatures by using Gas chromatography-mass spectroscopy

\begin{tabular}{|c|c|c|c|c|c|c|}
\hline \multirow{3}{*}{ Identified compound } & \multicolumn{6}{|c|}{ Collection temperature $\left({ }^{\circ} \mathrm{C}\right)$} \\
\hline & 80 & $90-92$ & 99-102 & $120-123$ & $145-150$ & $80-150$ \\
\hline & \multicolumn{6}{|c|}{ Compound percent (\%) } \\
\hline \multicolumn{7}{|l|}{ Acid compound } \\
\hline butanoic acid & 1.91 & 1.77 & 1.37 & 1.79 & 2.23 & 4.58 \\
\hline 2-methoxyethyl acetate & 1.50 & 1.38 & 1.11 & 1.26 & 1.63 & 5.98 \\
\hline 4-hydroxy-butanoic acid & 8.98 & 9.02 & 8.17 & 6.84 & 7.89 & 8.11 \\
\hline 4-hydroxy-3-methoxy-butanoic acid & - & - & - & 1.44 & 0.84 & 1.42 \\
\hline Total & 12.39 & 12.17 & 10.65 & 11.33 & 12.59 & 20.09 \\
\hline \multicolumn{7}{|l|}{ Phenol compound } \\
\hline phenol & 14.69 & 16.60 & 15.20 & 12.48 & 15.79 & 5.93 \\
\hline 4-methyl-phenol & 2.78 & 4.47 & 3.88 & 3.13 & 5.32 & 2.04 \\
\hline 3-ethyl-phenol & 4.60 & 6.44 & 6.06 & 8.35 & 8.81 & 6.69 \\
\hline 2-methoxy-phenol & 16.39 & 15.40 & 11.70 & 9.33 & 8.27 & 12.60 \\
\hline 2,4-dimethyl-phenol & - & 1.41 & 1.56 & 1.09 & 1.73 & - \\
\hline 4-ethyl-phenol & 8.26 & 9.48 & 8.60 & 6.64 & 6.98 & 3.68 \\
\hline 2-methoxy-4-methyl-phenol & 4.06 & 4.20 & 3.59 & 2.92 & 2.40 & 3.41 \\
\hline 4-ethyl-2-methoxy-phenol & 2.97 & 3.16 & 2.75 & 2.03 & 1.73 & 3.46 \\
\hline 2,6-dimethoxy-phenol & 5.77 & 4.82 & 9.69 & 11.90 & 8.76 & 20.20 \\
\hline Total & 59.52 & 65.98 & 63.03 & 57.87 & 59.79 & 58.06 \\
\hline \multicolumn{7}{|l|}{ Ketone compound } \\
\hline 4-hydroxy-4-methyl-2-pentanone & 3.07 & 2.80 & 2.28 & 2.14 & 5.73 & - \\
\hline 1-hydroxy-3-methyl-2-butanone & - & - & 1.66 & 1.46 & 1.51 & - \\
\hline 1-methyl-2-propanone & - & - & 0.86 & 0.94 & - & - \\
\hline 3-methyl-2-cyclopentenone-1-one & 1.19 & - & 0.90 & 2.31 & 2.22 & 1.38 \\
\hline 2,5-dihydro-3,5-dimethyl-2-furanone & 2.11 & - & 1.57 & 1.65 & 1.41 & 1.78 \\
\hline 2-hydroxy-3-methyl-2-cyclopentenone-1-one & 3.37 & 3.40 & 3.76 & 3.46 & 1.25 & 2.07 \\
\hline 2,3-dimethyl-2-cyclopentenone-1-one & 2.10 & 2.28 & 2.00 & 1.76 & 1.69 & 1.79 \\
\hline maltol & 0.95 & 1.17 & 1.74 & 3.30 & 2.53 & 1.88 \\
\hline 2-nonanone & - & 1.05 & - & 0.89 & 1.02 & - \\
\hline 1-(2,6-dihydroxy-4-methoxyphenyl)-ethanone & - & - & - & 0.84 & 0.60 & 1.28 \\
\hline Total & 12.79 & 10.70 & 14.77 & 18.76 & 17.96 & 10.13 \\
\hline \multicolumn{7}{|l|}{ Other compounds } \\
\hline pyridine & 9.36 & 6.46 & 5.86 & 5.02 & 4.32 & 5.87 \\
\hline 4-methyl-1-penten-3-ol & 4.92 & 3.65 & 3.08 & 2.35 & - & - \\
\hline 3-propoxy-1-propene & - & - & - & 1.17 & 1.72 & 1.96 \\
\hline tetrahydro-2,5-dimethyl-furan & - & - & 1.30 & 1.50 & 1.66 & - \\
\hline 2,6-dimethyl-heptane & 1.02 & 1.04 & 1.31 & 2.00 & 1.96 & 3.89 \\
\hline Total & 15.30 & 11.15 & 11.55 & 12.04 & 9.66 & 11.72 \\
\hline
\end{tabular}

25.00, 20.00, 13.33 and $10.00 \%$ are shown in Table 3.

The residual bacterial count of the control group (Blank) toward S. typhimurium TA98 and TA100 was 1838 and 1500. For bamboo vinegars collected at temperatures of $90-92^{\circ} \mathrm{C}$, the residual bacterial count without S9 for various diluting percent contents was 0-1830 for TA98 and 87-1641 for TA100; for those with S9, it was 1605-2000 for TA98 and 1736-2249 for TA100. For wood vinegars at $105-109^{\circ} \mathrm{C}$, the range of the residual bacterial count without S9 was 607-2071 for TA98 and 1558-1917 for TA100, and with S9 was 1864-2242 for TA98 and 3181-3448 for TA100. Waleh et al. (1982) indicated that the residual bacteria rate of $S$. typhimurium must be over $80 \%$ of the control group to determine that the test group has no cytotoxicity for $S$. typhimurium. The residual bacteria rate (Survival, \%) toward TA98 and TA100 for bamboo vinegar without the S9 mix at a diluting percent content $33.3 \%$ or less, and with the 
Table 2. Various Compounds of wood vinegars collected from different temperatures by using Gas chromatography-mass spectroscopy

\begin{tabular}{|c|c|c|c|c|c|c|}
\hline \multirow{3}{*}{ Identified compound } & \multicolumn{6}{|c|}{ Collection temperature $\left({ }^{\circ} \mathrm{C}\right)$} \\
\hline & $80-81$ & $90-97$ & 105-109 & $125-133$ & 153-159 & $80-159$ \\
\hline & \multicolumn{6}{|c|}{ Compound ratio (\%) } \\
\hline \multicolumn{7}{|l|}{ Acid compound } \\
\hline butanoic acid & 4.74 & 2.87 & 2.70 & 1.48 & 6.80 & 3.10 \\
\hline 2-methoxyethyl acetate & 3.96 & 3.29 & 2.66 & 1.27 & 2.43 & 4.36 \\
\hline 4-hydroxy-butanoic acid & 5.81 & 4.69 & 4.15 & 1.52 & 5.01 & 3.01 \\
\hline Total & 14.51 & 10.85 & 9.51 & 4.27 & 14.24 & 10.47 \\
\hline \multicolumn{7}{|l|}{ Phenol compound } \\
\hline phenol & 8.12 & 8.70 & 9.48 & 10.88 & 11.30 & 3.36 \\
\hline 4-methyl-phenol & 2.94 & 3.60 & 4.46 & 4.81 & 4.36 & 1.60 \\
\hline 3-ethyl-phenol & 4.26 & 5.28 & 6.50 & 6.33 & 6.94 & 7.21 \\
\hline 2-methoxy-phenol & 18.20 & 13.39 & 12.40 & 14.98 & 11.70 & 22.90 \\
\hline 2,4-dimethyl-phenol & - & 1.75 & 2.05 & 1.29 & 1.98 & - \\
\hline 4-ethyl-phenol & - & 1.17 & 1.32 & 1.45 & 1.09 & - \\
\hline 2-methoxy-4-methyl-phenol & 13.80 & 11.29 & 10.30 & 7.09 & 9.83 & 20.10 \\
\hline 4-ethyl-2-methoxy-phenol & 4.97 & 4.02 & 3.77 & 3.15 & 3.90 & 7.50 \\
\hline 2,6-dimethoxy-phenol & - & 1.03 & 1.00 & 0.54 & 1.04 & 2.36 \\
\hline Total & 52.29 & 50.23 & 51.28 & 50.55 & 52.11 & 65.03 \\
\hline \multicolumn{7}{|l|}{ Ketone compound } \\
\hline 4-hydroxy-4-methyl-2-pentanone & 3.75 & 2.07 & 2.01 & 1.10 & 3.62 & - \\
\hline 1-hydroxy-3-methyl-2-butanone & - & 0.89 & 1.37 & 1.15 & 1.39 & - \\
\hline 1-methyl-2-propanone & 2.24 & 1.79 & 1.51 & 2.18 & 1.13 & - \\
\hline 3-methyl-2-cyclopentenone-1-one & 2.26 & 1.97 & 2.26 & 0.81 & 1.50 & - \\
\hline 5-methoxy-2-pentanone & 2.08 & 1.62 & 1.54 & 2.15 & 1.55 & - \\
\hline 2,5-dihydro-3,5-dimethyl-2-furanone & 2.26 & 2.36 & 2.08 & 3.12 & 1.44 & 2.21 \\
\hline 2-hydroxy-3-methyl-2-cyclopentenone-1-one & 6.98 & 6.45 & 6.57 & 5.70 & 5.50 & 5.21 \\
\hline 2,3-dimethyl-2-cyclopentenone-1-one & 2.08 & 1.52 & 1.51 & 1.87 & 1.63 & 2.83 \\
\hline maltol & 1.98 & 3.58 & 4.09 & 5.00 & 3.10 & 2.68 \\
\hline 2,9-decanedione & - & 1.80 & 1.87 & 2.18 & 1.73 & - \\
\hline Total & 23.63 & 24.05 & 24.81 & 25.26 & 22.59 & 12.93 \\
\hline \multicolumn{7}{|l|}{ Other compounds } \\
\hline pyridine & 3.14 & 3.88 & 3.22 & 4.57 & 2.70 & 3.43 \\
\hline 4-methyl-1-penten-3-ol & 4.25 & 3.55 & 2.70 & 4.68 & - & - \\
\hline 2,5-dimethyl-furan & 2.18 & 1.25 & 1.04 & 1.51 & 2.62 & - \\
\hline 2-(1-methylethoxy)-1-propene & - & 1.15 & 1.42 & 1.75 & - & - \\
\hline 1-methoxy-cyclobutane & - & 2.89 & 3.57 & 4.61 & 3.30 & 3.65 \\
\hline 2,6-dimethyl-heptane & - & 2.15 & 2.45 & 2.80 & 2.44 & 4.49 \\
\hline Total & 9.57 & 14.87 & 14.40 & 19.92 & 11.06 & 11.57 \\
\hline
\end{tabular}

S9 mix at $25.00 \%$ or less was greater than $80 \%$. The wood vinegars for survival without the S9 mix at a diluting percent content of $50.00 \%$ or less toward TA98 but for TA100 at 100\% (original vinegar), and with the S9 mix at $33.33 \%$ or less toward TA98 and TA100 was higher than $80 \%$.

For vinegars collected at all different temperatures, the Survival results are shown in Table 4. The Survival of all bamboo vinegars collected from 80-150, over 80,
90-92, 99-102, $120-123$ and $145-150^{\circ} \mathrm{C}$ without the S9 mix at a diluting percent content of $33.33 \%$ or less were all higher than those for Blank by more than $80 \%$. However, the Survival of the bamboo vinegar collected at temperatures of $99-102^{\circ} \mathrm{C}$ at a diluting percent content of $25 \%$ showed that the cytotoxicity toward $S$. typhimurium TA98 and TA100 with the S9 mix was lower than $80 \%$, indicating "with toxicity". For the collected temperatures of all wood vinegars at 80-159, 80-90, 
Table 3. Cytotoxicity of bamboo vinegar collected at the temperature of $90-92^{\circ} \mathrm{C}$ and wood vinegar collected from the temperature at $105-$ $109^{\circ} \mathrm{C}$ toward Salmonella typhimurium TA98 and TA100 without the S9 or with the S9 mix

\begin{tabular}{|c|c|c|c|c|c|c|c|c|c|}
\hline \multirow{3}{*}{$\begin{array}{c}\text { S9 } \\
\text { mixture }\end{array}$} & \multirow{3}{*}{$\begin{array}{c}\text { Diluting } \\
\text { percent } \\
\text { content } \\
(\%)\end{array}$} & \multicolumn{4}{|c|}{ Bamboo vinegar $\left(90-92^{\circ} \mathrm{C}\right)$} & \multicolumn{4}{|c|}{ Wood vinegar $\left(105-109^{\circ} \mathrm{C}\right)$} \\
\hline & & TA98 & $\begin{array}{l}\text { Survival }{ }^{1)} \\
\text { (\%) }\end{array}$ & TA100 & $\begin{array}{c}\text { Survival } \\
\text { (\%) }\end{array}$ & TA98 & $\begin{array}{c}\text { Survival } \\
(\%)\end{array}$ & TA100 & $\begin{array}{c}\text { Surviva } \\
(\%)\end{array}$ \\
\hline & & $1838(127.50)^{(3)}$ & 100.00 & $1500(145.26)^{\text {de }}$ & 100.00 & $1838(127.50)^{\mathrm{cd}}$ & 100.00 & $1500(145.26)^{\mathrm{a}}$ & 100.00 \\
\hline \multirow{7}{*}{$-\mathrm{S} 9$} & Original vinegar & $0(00.00)^{\mathrm{a}}$ & 0.00 & $87(19.63)^{\mathrm{a}}$ & 5.82 & $607(96.34)^{\mathrm{a}}$ & 33.01 & $1558(130.18)^{a}$ & 103.87 \\
\hline & 50.00 & $336(70.53)^{\mathrm{b}}$ & 18.26 & $285(15.13)^{\mathrm{b}}$ & 19.00 & $1938(110.02)^{\mathrm{de}}$ & 105.46 & $2093(81.40)^{\mathrm{c}}$ & 139.51 \\
\hline & 33.33 & $1652(176.22)^{c}$ & 89.86 & $1284(111.72)^{\mathrm{c}}$ & 85.58 & $1602(147.16)^{b}$ & 87.18 & $1604(222.67)^{\mathrm{a}}$ & 106.93 \\
\hline & 25.00 & $1822(67.02)^{c}$ & 99.13 & $1201(66.98)^{\mathrm{c}}$ & 80.04 & $1653(89.29)^{\mathrm{be}}$ & 89.95 & $1525(184.19)^{\mathrm{a}}$ & 101.69 \\
\hline & 20.00 & $1736(50.01)^{c}$ & 94.43 & $1264(12.29)^{\mathrm{c}}$ & 84.27 & $1844(135.19)^{\mathrm{cd}}$ & 100.31 & $1637(29.69)^{\mathrm{a}}$ & 109.11 \\
\hline & 13.33 & $1829(147.70)^{\mathrm{c}}$ & 99.53 & $1353(150.01)^{\mathrm{cd}}$ & 90.20 & $1626(114.02)^{\mathrm{be}}$ & 88.48 & $1724(104.84)^{\mathrm{ab}}$ & 114.93 \\
\hline & 10.00 & $1830(155.52)^{\mathrm{c}}$ & 99.56 & $1641(120.79)^{e}$ & 109.42 & $2071(128.16)^{e}$ & 112.68 & $1917(156.16)^{\text {bc }}$ & 127.82 \\
\hline \multirow{6}{*}{ S9 } & Blank & $2165(75.75)^{c}$ & 100.00 & $2585(77.60)^{c}$ & 100.00 & $2165(75.75)^{\mathrm{cd}}$ & 100.00 & $2585(77.60)^{\mathrm{a}}$ & 100.00 \\
\hline & 33.33 & $1605(43.92)^{\mathrm{a}}$ & 74.16 & $1736(137.58)^{\mathrm{a}}$ & 67.15 & $1864(93.25)^{\mathrm{a}}$ & 86.13 & $3181(122.27)^{\mathrm{d}}$ & 123.03 \\
\hline & 25.00 & $1960(104.01)^{\mathrm{b}}$ & 90.53 & $2209(131.53)^{\mathrm{b}}$ & 85.46 & $2145(82.85)^{\mathrm{b}}$ & 99.11 & $3139(151.73)^{\mathrm{cd}}$ & 121.43 \\
\hline & 20.00 & $1938(129.55)^{b}$ & 89.53 & $2243(79.43)^{\mathrm{b}}$ & 86.75 & $2640(119.93)^{\mathrm{d}}$ & 121.96 & $3001(74.71)^{b c}$ & 116.08 \\
\hline & 13.33 & $2046(117.96)^{\mathrm{bc}}$ & 94.53 & $2885(98.43)^{d}$ & 111.60 & $2337(104.64)^{c}$ & 107.98 & $2938(22.90)^{b}$ & 113.65 \\
\hline & 10.00 & $2000(113.21)^{\mathrm{bc}}$ & 92.39 & $2249(139.96)^{b}$ & 87.00 & $2242(107.34)^{\mathrm{cd}}$ & 103.59 & $3448(41.04)^{\mathrm{e}}$ & 133.38 \\
\hline
\end{tabular}

\footnotetext{
${ }^{1)}$ Survival (\%) = (the bacterial count of test group / the bacterial count of control group) $* 100$

${ }^{2)}$ Blank (the control group) was added without either bamboo or wood vinegars

${ }^{3)}$ Values (standard deviation) within a transverse with the different superscripts are significantly different $(\rho<0.05)$ by Duncan's multiple range tests
}

Table 4. Survival of various bamboo/wood vinegars collected at different temperatures toward Salmonella typhimurium TA98 and TA100 without the S9 or with the S9 mix

\begin{tabular}{|c|c|c|c|c|c|c|c|c|c|c|c|c|c|c|}
\hline \multirow{3}{*}{\multicolumn{2}{|c|}{ Specimens }} & \multirow{3}{*}{$\begin{array}{c}\text { Diluting } \\
\text { percent } \\
\text { content (\%) }\end{array}$} & \multicolumn{12}{|c|}{ Collection temperature $\left({ }^{\circ} \mathrm{C}\right)$} \\
\hline & & & \multicolumn{2}{|c|}{80} & \multicolumn{2}{|c|}{$90-92$} & \multicolumn{2}{|c|}{$99-102$} & \multicolumn{2}{|c|}{$120-123$} & \multicolumn{2}{|c|}{$145-150$} & \multicolumn{2}{|c|}{$80-150$} \\
\hline & & & TA98 & TA100 & TA98 & TA100 & TA98 & TA100 & TA98 & TA100 & TA98 & TA100 & TA98 & TA100 \\
\hline \multirow{9}{*}{$\begin{array}{l}\text { Bamboo } \\
\text { vinegars }\end{array}$} & \multirow{5}{*}{-S9 } & 33.33 & 95.16 & 85.42 & 89.86 & 85.58 & 91.69 & 90.18 & 109.12 & 90.76 & 95.92 & 112.16 & 109.79 & 104.98 \\
\hline & & 25.00 & 115.54 & 88.91 & 99.13 & 80.04 & 99.13 & 105.82 & 104.13 & 115.42 & 90.86 & 99.82 & 112.82 & 102.42 \\
\hline & & 20.00 & 86.43 & 109.11 & 94.43 & 84.27 & 84.64 & 86.20 & 111.19 & 115.69 & 107.04 & 123.40 & 124.23 & 108.62 \\
\hline & & 13.33 & 95.30 & 88.11 & 99.53 & 90.20 & 99.53 & 90.56 & 114.93 & 118.91 & 109.61 & 102.42 & 95.88 & 128.20 \\
\hline & & 10.00 & 106.58 & 94.69 & 99.56 & 109.42 & 101.16 & 84.53 & 113.75 & 111.47 & 122.63 & 96.44 & 127.98 & 119.71 \\
\hline & \multirow{4}{*}{ S9 } & 25.00 & 88.81 & 92.83 & 90.53 & 85.46 & 76.36 & 70.81 & 89.79 & 96.39 & 103.87 & 122.07 & 86.94 & 89.12 \\
\hline & & 20.00 & 95.40 & 84.84 & 89.53 & 86.75 & 86.53 & 106.65 & 113.32 & 90.36 & 89.11 & 89.27 & 85.19 & 89.74 \\
\hline & & 13.33 & 92.12 & 120.27 & 94.53 & 111.60 & 98.66 & 104.95 & 126.73 & 115.78 & 143.39 & 140.28 & 84.85 & 97.83 \\
\hline & & 10.00 & 84.19 & 99.79 & 92.39 & 87.00 & 94.73 & 83.29 & 117.83 & 99.02 & 120.54 & 98.09 & 102.71 & 131.10 \\
\hline \multirow{2}{*}{\multicolumn{2}{|c|}{ Specimens }} & Diluting percent & \multicolumn{2}{|c|}{$80-81$} & \multicolumn{2}{|c|}{$90-97$} & \multicolumn{2}{|c|}{$105-109$} & \multicolumn{2}{|c|}{$125-133$} & \multicolumn{2}{|c|}{$153-159$} & \multicolumn{2}{|c|}{$80-159$} \\
\hline & & contuntu (\%) & TA98 & TA100 & TA98 & TA100 & TA98 & TA100 & TA98 & TA100 & TA98 & TA100 & TA98 & TA100 \\
\hline \multirow{9}{*}{$\begin{array}{c}\text { Wood } \\
\text { vinegars }\end{array}$} & \multirow{5}{*}{-S9 } & 33.33 & 90.01 & 102.58 & 100.42 & 111.73 & 87.18 & 106.93 & 90.13 & 133.16 & 83.26 & 140.98 & 85.46 & 111.56 \\
\hline & & 25.00 & 103.97 & 106.67 & 109.56 & 107.64 & 89.95 & 101.69 & 103.16 & 138.31 & 81.72 & 133.07 & 88.08 & 129.24 \\
\hline & & 20.00 & 110.83 & 110.93 & 117.45 & 94.67 & 100.31 & 109.11 & 96.52 & 132.09 & 117.75 & 177.20 & 99.87 & 136.58 \\
\hline & & 13.33 & 113.04 & 96.71 & 102.90 & 94.40 & 88.48 & 114.93 & 83.21 & 130.80 & 81.05 & 131.64 & 101.29 & 165.96 \\
\hline & & 10.00 & 108.52 & 131.07 & 91.53 & 156.44 & 112.68 & 127.82 & 105.24 & 139.91 & 115.27 & 145.33 & 113.15 & 162.02 \\
\hline & \multirow{4}{*}{ S9 } & 25.00 & 93.36 & 93.62 & 109.47 & 100.49 & 99.11 & 121.43 & 122.68 & 126.99 & 104.80 & 109.99 & 86.71 & 94.26 \\
\hline & & 20.00 & 115.51 & 91.06 & 92.98 & 93.26 & 121.96 & 116.08 & 90.50 & 94.58 & 84.96 & 99.43 & 90.78 & 85.82 \\
\hline & & 13.33 & 131.04 & 104.53 & 121.68 & 108.55 & 107.98 & 113.65 & 103.05 & 136.98 & 100.75 & 142.46 & 98.68 & 88.24 \\
\hline & & 10.00 & 101.37 & 107.14 & 111.80 & 130.17 & 103.59 & 133.38 & 102.57 & 94.91 & 102.56 & 128.98 & 95.61 & 108.64 \\
\hline
\end{tabular}


91-100, 105-109, 101-120, 121-140 and $141-159^{\circ} \mathrm{C}$ without the S9 mix, the Survival for the diluting percent content at $33.33 \%$ or less were all higher than those for the control by more than $80 \%$ and for those with the S9 mix at $25 \%$ or less. It is said that the Survival of bamboo/wood vinegars collected at all different temperatures at a diluting percent content of $20.00 \%$ less for either with or without S9 mix is no cytotoxicity absolutely, and the dose for the mutagenicity test can be selected according to the results above.

\section{Mutagenicity of bamboo/wood vinegars}

Ames et al. (1975) reported that the number of spontaneous revertants induced by the specimen is less than for the control group by more than two times; the specimen has no mutagenicity. Table 5 shows the muta-

Table 5. Mutagenicity of bamboo/wood vinegars collected at the temperatures of 90-92/105-109 ${ }^{\circ} \mathrm{C}$ toward Salmonella typhimurium TA98 and TA100 without the S9 or with the S9 mix

\begin{tabular}{|c|c|c|c|c|c|c|c|c|c|}
\hline \multirow{3}{*}{$\begin{array}{c}\text { S9 } \\
\text { mixture }\end{array}$} & Diluting & \multicolumn{4}{|c|}{ Bamboo vinegar $\left(90-92^{\circ} \mathrm{C}\right)$} & \multicolumn{4}{|c|}{ Wood vinegar $\left(105-109^{\circ} \mathrm{C}\right)$} \\
\hline & $\begin{array}{c}\text { percent content } \\
(\%)\end{array}$ & TA98 & $\mathrm{MR}^{1)}$ & TA100 & MR & TA98 & MR & TA100 & MR \\
\hline & Blank $^{2)}$ & $65(4.93)^{\mathrm{b} 3)}$ & 1.00 & $132(4.36)^{b}$ & 1.00 & $65(4.93) \mathrm{b}$ & 1.00 & $132(4.36)^{\mathrm{d}}$ & 1.00 \\
\hline \multirow{4}{*}{$-\mathrm{S} 9$} & 25.00 & $53(8.19)^{\mathrm{a}}$ & 0.81 & $129(3.00)^{b}$ & 0.98 & $54(5.29)^{\mathrm{a}}$ & 0.83 & $98(6.11)^{\mathrm{b}}$ & 0.74 \\
\hline & 20.00 & $42(6.66)^{a}$ & 0.64 & $121(4.51)^{\mathrm{ab}}$ & 0.91 & $51(1.73)^{\mathrm{a}}$ & 0.78 & $120(10.12) \mathrm{c}$ & 0.91 \\
\hline & 13.33 & $53(4.04)^{a}$ & 0.81 & $109(5.69)^{\mathrm{a}}$ & 0.83 & $50(6.03)^{\mathrm{a}}$ & 0.76 & $86(7.81)^{\mathrm{ab}}$ & 0.65 \\
\hline & 10.00 & $41(8.00)^{\mathrm{a}}$ & 0.63 & $115(10.26)^{\mathrm{a}}$ & 0.87 & $51(8.50)^{\mathrm{a}}$ & 0.79 & $84(2.31)^{\mathrm{a}}$ & 0.63 \\
\hline \multirow{4}{*}{ S9 } & Blank & $76(0.58)^{\mathrm{b}}$ & 1.00 & $140(12.06)^{\mathrm{a}}$ & 1.00 & $76(0.58)^{\mathrm{a}}$ & 1.00 & $140(12.06)^{\mathrm{ab}}$ & 1.00 \\
\hline & 20.00 & $69(4.51)^{\mathrm{ab}}$ & 0.90 & $195(10.97)^{b}$ & 1.39 & $81(9.64)^{b}$ & 1.06 & $160(3.51)^{\mathrm{be}}$ & 1.14 \\
\hline & 13.33 & $73(6.66)^{\mathrm{b}}$ & 0.96 & $204(13.23)^{b}$ & 1.45 & $92(3.21)^{\mathrm{bc}}$ & 1.20 & $188(15.52)^{\mathrm{d}}$ & 1.34 \\
\hline & 10.00 & $74(5.20)^{\mathrm{b}}$ & 0.97 & $206(3.06)^{b}$ & 1.47 & $82(7.21)^{\mathrm{b}}$ & 1.07 & $182(15.82)^{\mathrm{cd}}$ & 1.29 \\
\hline
\end{tabular}

1) MR (Mutagenicity ratio) = induced revertants per plate/spontaneous revertants per plate (Control);

${ }^{2)}$ Blank (the control group) was added without either bamboo or wood vinegars

${ }^{3)}$ Values (standard deviation) within a transverse with the different superscripts are significantly different $(\rho<0.05)$ by Duncan's multiple range tests

Table 6. Survival of various bamboo/wood vinegars collected at different temperatures toward Salmonella typhimurium TA98 and TA100 without the S9 or with the S9 mix

\begin{tabular}{|c|c|c|c|c|c|c|c|c|c|c|c|c|c|c|}
\hline \multirow{3}{*}{\multicolumn{2}{|c|}{ Specimens }} & \multirow{3}{*}{$\begin{array}{c}\text { Diluting } \\
\text { percent } \\
\text { content (\%) }\end{array}$} & \multicolumn{12}{|c|}{ Collection temperature $\left({ }^{\circ} \mathrm{C}\right)$} \\
\hline & & & \multicolumn{2}{|c|}{80} & \multicolumn{2}{|c|}{$90-92$} & \multicolumn{2}{|c|}{ 99-102 } & \multicolumn{2}{|c|}{$120-123$} & \multicolumn{2}{|c|}{$145-150$} & \multicolumn{2}{|c|}{$80-150$} \\
\hline & & & TA98 & TA100 & TA98 & TA100 & TA98 & TA100 & TA98 & TA100 & TA98 & TA100 & TA98 & TA100 \\
\hline \multirow{7}{*}{$\begin{array}{l}\text { Bamboo } \\
\text { vinegars }\end{array}$} & \multirow{4}{*}{$-\mathrm{S} 9$} & 25.00 & 0.72 & 1.08 & 0.81 & 0.98 & - & - & 0.74 & 0.63 & 0.68 & 0.50 & 0.62 & 0.80 \\
\hline & & 20.00 & 0.68 & 1.02 & 0.64 & 0.91 & 0.65 & 0.90 & 0.81 & 0.62 & 0.59 & 0.54 & 0.67 & 0.76 \\
\hline & & 13.33 & 0.70 & 0.86 & 0.81 & 0.83 & 0.72 & 0.78 & 0.52 & 0.57 & 0.57 & 0.50 & 0.68 & 0.72 \\
\hline & & 10.00 & 0.61 & 0.93 & 0.63 & 0.87 & 0.75 & 1.00 & 0.69 & 0.77 & 0.69 & 0.56 & 0.73 & 0.60 \\
\hline & \multirow{3}{*}{ S9 } & 20.00 & 1.10 & 1.47 & 0.90 & 1.39 & 0.88 & 1.57 & 1.18 & 1.19 & 1.32 & 1.32 & 1.16 & 0.83 \\
\hline & & 13.33 & 0.91 & 1.51 & 0.96 & 1.45 & 0.89 & 1.62 & 1.14 & 1.29 & 1.22 & 1.26 & 1.21 & 1.04 \\
\hline & & 10.00 & 1.04 & 1.42 & 0.97 & 1.47 & 0.96 & 1.66 & 1.00 & 1.28 & 1.20 & 1.40 & 1.35 & 1.05 \\
\hline \multirow{2}{*}{\multicolumn{2}{|c|}{ Specimens }} & Diluting percent & \multicolumn{2}{|c|}{$80-81$} & \multicolumn{2}{|c|}{$90-97$} & \multicolumn{2}{|c|}{$105-109$} & \multicolumn{2}{|c|}{$125-133$} & \multicolumn{2}{|c|}{$153-159$} & \multicolumn{2}{|c|}{$80-159$} \\
\hline & & content (\%) & TA98 & TA100 & TA98 & TA100 & TA98 & TA100 & TA98 & TA100 & TA98 & TA100 & TA98 & TA100 \\
\hline \multirow{7}{*}{$\begin{array}{c}\text { Wood } \\
\text { vinegars }\end{array}$} & \multirow{4}{*}{$-\mathrm{S} 9$} & 25.00 & 0.84 & 1.19 & 1.06 & 0.90 & 0.83 & 0.74 & 0.75 & 0.76 & 0.69 & 0.50 & 0.70 & 0.98 \\
\hline & & 20.00 & 0.88 & 1.04 & 0.82 & 0.90 & 0.78 & 0.91 & 0.89 & 0.74 & 0.87 & 0.54 & 0.73 & 0.99 \\
\hline & & 13.33 & 0.98 & 0.80 & 0.89 & 0.66 & 0.76 & 0.65 & 0.95 & 0.58 & 0.86 & 0.49 & 0.93 & 0.62 \\
\hline & & 10.00 & 0.73 & 0.82 & 0.83 & 0.68 & 0.79 & 0.63 & 0.85 & 0.71 & 0.82 & 0.49 & 0.82 & 0.76 \\
\hline & \multirow{3}{*}{ S9 } & 20.00 & 1.07 & 1.27 & 0.99 & 1.14 & 1.06 & 1.14 & 1.07 & 1.22 & 1.22 & 1.32 & 1.06 & 1.15 \\
\hline & & 13.33 & 1.11 & 1.39 & 1.16 & 1.39 & 1.20 & 1.34 & 1.14 & 1.22 & 1.28 & 1.32 & 1.14 & 1.26 \\
\hline & & 10.00 & 1.09 & 1.25 & 1.08 & 1.26 & 1.07 & 1.29 & 1.06 & 1.26 & 1.11 & 1.34 & 1.15 & 1.28 \\
\hline
\end{tabular}


genicity results for the bamboo/wood vinegars collected at temperatures of $90-92 / 105-109^{\circ} \mathrm{C}$ with a diluting percent content of $25.00,20.00,13.33$ and $10.00 \%$ for $S$. typhimurium TA98 and TA100 without the S9 mix and with the S9 for a diluting percent content of 20.00, 13.33 and $10.00 \%$. The spontaneous revertants of Blank were 65 for TA98 and 132 for TA100, and of bamboo/wood vinegars without the S9 mix were from 41 to 54 for TA98

Table 7. Antimutagenicity of bamboo/wood vinegars collected at the temperatures of 90-92/105-109 ${ }^{\circ} \mathrm{C}$ toward Salmonella typhimurium TA98 and TA100 without the S9 or with the S9 mix

\begin{tabular}{|c|c|c|c|c|c|c|c|c|c|}
\hline \multirow[b]{2}{*}{ Mutagens } & \multirow{2}{*}{$\begin{array}{l}\text { Diluting } \\
\text { percent } \\
\text { content } \\
(\%)\end{array}$} & \multicolumn{4}{|c|}{ Bamboo vinegar $\left(90-92^{\circ} \mathrm{C}\right)$} & \multicolumn{4}{|c|}{ Wood vinegar $\left(105-109^{\circ} \mathrm{C}\right)$} \\
\hline & & TA98 & $\begin{array}{c}\text { Inhibition }^{1)} \\
\text { (\%) }\end{array}$ & TA100 & $\begin{array}{c}\text { Inhibition } \\
(\%)\end{array}$ & TA98 & $\begin{array}{l}\text { Inhibition } \\
(\%)\end{array}$ & TA100 & $\begin{array}{c}\text { Inhibition } \\
(\%)\end{array}$ \\
\hline \multirow{5}{*}{$\begin{array}{l}\text { NQNO } \\
(1 \mu \mathrm{g} / \\
\text { plate) }\end{array}$} & Blank $^{2)}$ & $1128(93.15)^{\mathrm{c3s}}$ & 0.00 & $1445(75.80)^{c}$ & 0.00 & $1128(93.15)^{\mathrm{b}}$ & 0.00 & $1445(75.8)^{\mathrm{e}}$ & 0.00 \\
\hline & 25.00 & $807(48.22)^{\mathrm{a}}$ & 30.18 & $425(52.79)^{\mathrm{a}}$ & 77.65 & $906(43.27)^{\mathrm{a}}$ & 20.89 & $579(61.13)^{\mathrm{b}}$ & 65.92 \\
\hline & 20.00 & $841(71.59)^{\mathrm{a}}$ & 27.04 & $446(35.80)^{\mathrm{a}}$ & 76.05 & $925(70.27)^{\mathrm{a}}$ & 19.07 & $620(39.95)^{b}$ & 62.82 \\
\hline & 13.33 & $891(85.05)^{\mathrm{ab}}$ & 22.33 & $594(32.92)^{\mathrm{b}}$ & 64.80 & $1058(64.71)^{\mathrm{b}}$ & 6.59 & $794(57.58)^{\mathrm{c}}$ & 49.57 \\
\hline & 10.00 & $985(64.26)^{b}$ & 13.49 & $616(42.71)^{\mathrm{b}}$ & 63.15 & $1084(64.16)^{\mathrm{b}}$ & 4.14 & $977(61.78)^{\mathrm{d}}$ & 35.65 \\
\hline \multicolumn{2}{|c|}{ Spontaneous revertants } & $65(4.93)$ & & $132(4.36)$ & & $65(4.93)$ & & $132(4.36)$ & \\
\hline \multirow{4}{*}{$\begin{array}{l}\text { AFB1 } \\
(5 \mu \mathrm{g} / \\
\text { plate) }\end{array}$} & Blank & $1824(57.86)^{\mathrm{d}}$ & 0.00 & $2406(86.00)^{\mathrm{e}}$ & 0.00 & $1824(57.86)^{c}$ & 0.00 & $2406(86.00)^{\mathrm{d}}$ & 0.00 \\
\hline & 20.00 & $1114(6.93)^{\mathrm{b}}$ & 40.63 & $843(25.48)^{\mathrm{b}}$ & 68.97 & $1498(83.21)^{\mathrm{ab}}$ & 18.65 & $619(21.39)^{\mathrm{a}}$ & 78.89 \\
\hline & 13.33 & $1292(73.32)^{\mathrm{c}}$ & 30.44 & $1012(49.27)^{c}$ & 61.53 & $1510(45.03)^{\mathrm{b}}$ & 17.97 & $769(45.71)^{\mathrm{b}}$ & 72.27 \\
\hline & 10.00 & $1319(44.38)^{c}$ & 28.88 & $1202(35.04)^{\mathrm{d}}$ & 53.14 & $1587(77.60)^{\mathrm{b}}$ & 13.58 & $1051(55.18)^{\mathrm{c}}$ & 59.79 \\
\hline \multicolumn{2}{|c|}{ Spontaneous revertants } & $76(0.58)$ & & $140(12.06)$ & & $76(0.58)$ & & $140(12.06)$ & \\
\hline
\end{tabular}

1) Inhibition $(\%)=\left[1-\left(\right.\right.$ Number of his ${ }^{+}$revertants in the presence of the test vinegar - Number of spontaneous revertants) / (Number of his $^{+}$revertants in the absence of the test vinegar - Number of spontaneous revertants)] $\times 100$

2) Blank (the control group) was added without either bamboo or wood vinegars

${ }^{3)}$ Values (standard deviation) within a transverse with the different superscripts are significantly different $(\rho<0.05)$ by Duncan's multiple range tests

Table 8. Inhibition of various bamboo/wood vinegars collected at different temperatures toward Salmonella typhimurium TA98, TA100 without the S9 or with the S9 mix

Unit: \%

\begin{tabular}{|c|c|c|c|c|c|c|c|c|c|c|c|c|c|c|}
\hline & & & & & & & Colle & tion ten & peratur & $\left({ }^{\circ} \mathrm{C}\right)$ & & & & \\
\hline Specim & nens & percent & & 0 & & -92 & 99 & 102 & 120 & -123 & 145 & 150 & 80 & 150 \\
\hline & & content (\%) & TA98 & TA100 & TA98 & TA100 & TA98 & TA100 & TA98 & TA100 & TA98 & TA100 & TA98 & TA100 \\
\hline & & 25.00 & 25.03 & 70.14 & 30.18 & 77.65 & - & - & 27.85 & 74.45 & 2.76 & 81.77 & 22.96 & 68.97 \\
\hline & & 20.00 & 23.15 & 65.34 & 27.04 & 76.05 & 23.21 & 75.22 & 11.67 & 64.45 & 1.19 & 60.23 & 4.20 & 61.38 \\
\hline & NQQIVO & 13.33 & 12.80 & 60.64 & 22.33 & 64.80 & 20.58 & 58.91 & 4.08 & 61.55 & 1.00 & 40.71 & 0.75 & 57.31 \\
\hline Bamboo & & 10.00 & 11.29 & 59.45 & 13.49 & 63.15 & 15.18 & 57.97 & 1.07 & 28.52 & 0.63 & 18.18 & 0.19 & 42.74 \\
\hline & & 20.00 & 24.38 & 62.94 & 40.63 & 68.97 & 37.80 & 66.35 & 20.03 & 75.24 & 11.63 & 73.06 & 20.14 & 74.86 \\
\hline & $\mathrm{AFB}_{1}$ & 13.33 & 21.13 & 57.88 & 30.44 & 61.53 & 26.36 & 66.00 & 18.73 & 68.97 & 8.54 & 66.41 & 17.09 & 73.27 \\
\hline & & 10.00 & 18.31 & 37.43 & 28.88 & 53.14 & 24.26 & 54.88 & 13.20 & 59.88 & 0.92 & 60.50 & 7.44 & 58.44 \\
\hline Snecim & aens & Diluting percent & & -81 & & -97 & 105 & 109 & 125 & -133 & 153 & 159 & 80 & 159 \\
\hline Spectint & Heris & content (\%) & TA98 & TA100 & TA98 & TA100 & TA98 & TA100 & TA98 & TA100 & TA98 & TA100 & TA98 & TA100 \\
\hline & & 25.00 & 16.88 & 43.37 & 19.39 & 41.26 & 20.89 & 65.92 & 22.02 & 52.77 & 5.02 & 67.19 & 31.43 & 54.95 \\
\hline & & 20.00 & 5.46 & 40.58 & 12.23 & 39.77 & 19.07 & 62.82 & 8.59 & 48.81 & 1.76 & 53.94 & 22.02 & 52.82 \\
\hline & NQQIVO & 13.33 & 4.89 & 32.86 & 8.72 & 37.07 & 6.59 & 49.57 & 1.69 & 33.42 & -0.19 & 47.99 & 7.72 & 49.87 \\
\hline Wood & & 10.00 & 2.32 & 32.10 & 5.40 & 35.63 & 4.14 & 35.65 & 0.75 & 32.96 & -4.45 & 42.00 & 4.71 & 43.12 \\
\hline & & 20.00 & 18.96 & 61.88 & 20.71 & 71.68 & 18.65 & 78.89 & 16.94 & 69.18 & 7.13 & 70.56 & 25.06 & 71.15 \\
\hline & $\mathrm{AFB}_{1}$ & 13.33 & 15.75 & 50.14 & 17.09 & 62.28 & 17.97 & 72.27 & 15.22 & 64.76 & 6.52 & 62.67 & 15.60 & 66.32 \\
\hline & & & 11.67 & 12.03 & 8.93 & 61.88 & 13.58 & 59.79 & 14.99 & 59.06 & 3.62 & 59.35 & 11.56 & 64.53 \\
\hline
\end{tabular}


and from 84 to 129 for TA100. With the S9 mix, the spontaneous revertants of bamboo/wood vinegars were 69-92 for TA98 and 160-206 for TA100. The results on the same Table 5 also show that the bamboo/wood vinegars in the test range did not exceed spontaneous revertants by more than two times for TA98 and TA100 without/with S9 mix; that is, the mutagenicity ratio (MR) was less than 2. The spontaneous revertants of the other bamboo/wood vinegars collected at various temperatures at the ranges of the diluting percent content were smaller than those of the control group by more than two times; that is, the MR was also less than 2 (results not shown in this paper). The bamboo/wood vinegars, therefore, have no mutagenicity toward S. typhimurium TA98 and TA100.

The MR of the bamboo/wood vinegars collected at all different temperatures toward S. typhimurium TA98 and TA100 without the S9 mix for a diluting percent content of $25.00,20.00,13.33$ and $10.00 \%$ or with the S9 mix for a diluting percent content of 20.00, 13.33 and 10.00\% is shown in Table 6 . No matter what the vinegars were for all collected temperatures and $S$. typhimurium TA98 and TA100 without/with the S9 mix, the MR was less than 2. Neither mutagenicity nor toxicity was observed for bamboo/wood vinegars collected at various temperatures toward S. typhimurium TA 98 or TA 100 without/ with the S9 mix. Hence, without the S9 mix a diluting percent content of 25.00 to $10.00 \%$ and with S9 mix at 20.00 to $10.00 \%$ a diluting percent content was selected for the antimutagenic assay.

\section{Antimutagenicity of bamboo/wood vinegars}

In the present study, NQNO and AFB1 were used as direct mutagens requiring metabolic activation and indirect acting mutagen, respectively. Doses of mutagens, $1 \mu \mathrm{g}$ for NQNO and $5 \mu \mathrm{g}$ for AFB1, were selected from a dose-response curve of a preliminary experiment (Yen et al., 2001). The His ${ }^{+}$revertants of strain are less than those of the control group, said that with antimutagenic activities. Meanwhile, the inhibitory effect of the specimen is expressed by inhibition (\%), and the higher the inhibition, the more effective the antimutagenic activities (Maron and Ames, 1983). The inhibitory effects for one of the antimutagenicity results for the bamboo/wood vinegars collected at temperatures of $90-92 / 105-109^{\circ} \mathrm{C}$ with a diluting percent content of 25.00, 20.00, 13.33 and $10.00 \%$ for NQNO and at 20.00, 13.33 and $10.00 \%$ for $\mathrm{AFB}_{1}$ are summarized in Table 7.

The His ${ }^{+}$revertants of strain against the NQNO in Blank (without bamboo/wood vinegars) were 1128 for TA98, and 1445 for TA100, for AFB1: they were 1824 for TA98, and 2406 for TA100. The spontaneous revertants without NQNO were 65 for TA98 and 132 for TA100, and without AFB1 were 76 for TA98 and 140 for TA100. The His ${ }^{+}$revertants of strain (inhibition) against the NQNO for bamboo vinegar at $90-92^{\circ} \mathrm{C}$ with different diluting percent contents were 807-985 (30.18-13.49\%) for TA98 and 425-616 (77.65-63.15\%) for TA100, for wood vinegar at $105-109^{\circ} \mathrm{C}$ they were $906-1084(20.89-4.14 \%)$ for TA98 and 579-977 (65.92-35.65\%) for TA100. For AFB1, they were 1114-1319 (40.63-28.88\%) for TA98 and 843-
1202 (68.97-53.14\%) for TA100 from bamboo vinegar at $90-92^{\circ} \mathrm{C}$ with different diluting percents, from wood vinegar at $105-109^{\circ} \mathrm{C}$ they were $1498-1587$ (18.65-13.58\%) for TA98 and 619-1051 (78.89-59.79\%) for TA100. The results also showed that the higher diluting percent content, the greater the inhibition; as well as, no matter what the vinegar was, the inhibition for TA100 was greater than that of TA98.

The inhibition of the bamboo/wood vinegars collected at all different temperatures against the NQNO for diluting percent contents of 25.00, 20.00, 13.33 and $10.00 \%$ or against the $\mathrm{AFB}_{1}$ at $20.00,13.33$ and $10.00 \%$ is shown in Table 8. The inhibition of the bamboo vinegars to TA98 was $0.19-30.18 \%$ for NQNO and $0.92-40.63 \%$ for AFB1; they were better than that of wood vinegar, $-4.45-31.43 \%$ and $3.62-25.06 \%$. For both vinegars with TA100 against NQNO (18.18-81.77\%) and $\mathrm{AFB}_{1}$ (12.03-78.89\%), they were better than those for TA98. The antimutagenicity to NQNO was effective for bamboo/wood vinegars collected at various temperatures with a diluting percent content of $25.00 \%$ or less, and for $\mathrm{AFB}_{1}$, it was also effective at a $20.00 \%$ or less diluting percent content. Furthermore, the bamboo/wood vinegars showed that the inhibitory effect on NQNO or $\mathrm{AFB}_{1}$ toward TA100 was greater than that toward TA98. It is also indicated that the inhibition of the vinegars against $\mathrm{AFB}_{1}$ toward TA98 and TA100 is better than that against NQNO.

In this study, the main percent of the phenol and ketone compounds in the bamboo/wood vinegars collected from various different temperatures was 50.2365.98\% (Table 1) and 10.13-25.26\% (Table 2), resulting in no cytotoxicity (Table 4)/mutagenicity (Table 6) and with antimutagenic effect (Table 6) against strains. It is inferred that the phenol and ketone compounds may partially account for the biological action of bamboo/wood vinegars.

\section{CONCLUSIONS}

The compounds, safety evaluation and antimutagenic activity of bamboo/wood vinegars were investigated. The compounds of bamboo/wood vinegars include the acid, phenol, ketone and the other compounds. The main percent content of the phenol compounds for bamboo vinegars was phenol (5.93-16.60\%) and 2-methoxyphenol (8.27-16.39\%). For wood vinegars, the main compounds were 2-methoxy-phenol (11.70-22.90\%) and 2-methoxy-4-methyl-phenol (7.09-20.10\%). The diluting percent content of vinegars was lower than $20.00 \%$ or less with the S9 mix and $33.33 \%$ or less without the S9 mix in cytotoxicity and mutagenicity toward S. typhimurium TA98 and TA100 because the rest of the bacterium at these percent contents was higher than $80 \%$ of the control, and the mutagenicity ratio was less than for the control group by more than two times. The diluting percent content of vinegars of $20.00 \%$ or less, expressed an amount-dependent inhibitory effect against both the mutagenicity of 4-nitroquinoline-N-oxide (NQNO) with $1 \mu \mathrm{g} /$ plate and aflatoxin $\mathrm{B}_{1}\left(\mathrm{AFB}_{1}\right)$ with $5 \mu \mathrm{g} /$ plate in $S$. typhimurium TA98 and TA100. It is suggested that 
bamboo/wood vinegars with a diluting percent content to the least extent of $20.00 \%$ or less had no cytotoxicity and mutagenicity, and their antimutagenicity with NQNO and $\mathrm{AFB}_{1}$ was effective.

\section{ACKNOWLEDGEMENTS}

The authors offer the sincere appreciation to the Forestry Bureau, Council of Agriculture Executive with No. 98-04.4-B-P-14 for financial support.

\section{REFERENCES}

Ames, B. N., J. McCann and E. Yamasaki 1975 Methods for Detecting Carcinogens and Mutagens with the Salmonella/ Mammalian-Microsome Mutagenicity Test. Mutat. Res., $\mathbf{3 1}$ : 347-364

Ames, B. N. and J. McCann 1976 Detection of Carcinogens as Mutagenes in the Salmonella/Microsome Test: Assay of 300 Chemicals. Proc. Natl. Acad. Sci. U.S.A., 73: 950-954

Chen, C. H, K. T. Lu, L. W. Hung, C. T. Liu and C. H. Yen 2006 Manufacture of Wood Charcoals and Wood Vinegars from Floating Wood and Their Utilization on the Culture of Plants (I) Manufacture of Wood Charcoals and Wood Vinegars from Floating Softwood. Quarterly Journal of Forest Research, 28(4): $87-98$

Chen, P. K., S. C. Wu, G. S. Hwang and H. C. Lin 2010 Investigation on Basic Properties and Antibacterial Activity of Bamboo/Wood Vinegars Collected from Different Temperature. J. Agric For. (NCYU), 7(2): 95-117

Council of Agriculture 2004 Certified Agricultural Standards of Forest Products. COA, Executive Yuan, Taiwan ROC

Duh, P. D. and G. C. Yen 1997 Antioxidant activity of three herbal water extracts. Food Chem., 60: 639-645

Hageta, Y. 2004 Application of Wood/Bamboo Vinegar on the Cultivation of Grape. Nobunkyou Publication, pp. 84-85.

Ho, H. M., W. R. Kuo, Chia-Wen Peng, G. S. Hwang and H. C. Lin 2013 Investigation of Yield and Seedling Growth of Cabbage from Cultural Media with Moso Bamboo Charcoal. J. Agric For. (NCYU), 10(1): 43-60

Horne, P. A. and T. W. Paul 1996 Influence of Temperature on the Products from the Flash Pyrolysis of Biomass. Fuel, 75(9): 1051-1059

Huang, Y. P., C. W. Peng, Y. H. Huang, T. R. Tsai, W. R. Kuo, and H. C. Lin 2011 Investigation of Mikania micrantha Charcoal Applied on Cultural Media. Materials Science Forum, 685: 216-229

Hwang, G. S., C. L. Ho, H. Y. Yu and Y. C. Su 2006 Bamboo Vinegar Collected during Charcoal Making with an Earthen Kiln and Its Basic Properties. Taiwan J For Sci., 29(1): 1-15

Hwang, G. S., Y. J. Lin, C. L. Ho and H. Y. Yu 2008 Study on Charcoal Marking with Branches and Tops Wood of Cryptomeria japonica Using an Earthen Kiln Abstracts of The 2008 Annual meeting of The Chinese Forest Products Association, pp. 27-33

Ikimoto, T. and O. Ikeshima 2000 Usages of Bamboo Charcoal and Bamboo Vinegar. Nobunkyou Publication, pp. 89-107

Ishihara, S. 1996 Development of Wood-based Charcoal Materials, Mokuzaigakkaishi, 42(8): 717-723

Kobahasi, Y. 2004 Reductive Effectives of Agricultural Chemical. Nobunkyou Publication, pp. 146-149

Kou, C. W. 2004 Effects of Heating Rates on Fundamental Properties of Vinegar during Bamboo Carbonization and Its Application on Inhibit Plant Pathogenic Bacteria, Master thesis of National Chung University, pp. 1-76

Lin, H. C., T. Ohuchi, Y. Murase, T. C. Shiah, S. L. Shieh, P. C. Chiu, Y. M. Juan and S. C. Cheng 2006 Application of Bamboo Vinegar with Vacuum Process to Evaluate Fungi Resistance of Bamboo Materials. Journal of the Faculty of Agriculture
Kyushu University. Japan, 51(1): 5-11.

Lin, H. C. and T. C. Shiah 2006 Evaluation of Fungi Resistance of Moso Bamboo Materials Using Bamboo Vinegar with Smoking Process. Quart. Journal Forest Research of Taiwan. Taiwan $R O C, \mathbf{2 8}(2): 51-66$

Lin, H. C., Y. Murase, T. C. Shiah, G. S. Hwang, P. K. Chen and W. L. Wu 2008 Application of Moso Bamboo Vinegar with Different Collection Temperatures to Evaluate Fungi Resistance of Moso Bamboo Materials. Journal of the Faculty of Agriculture Kyushu University. Japan, 53(1): 107-113

Lin, H. C., N. Fujimoto, G. S. Hwang, S. C. Wu, C. Y. Liu, P. J. Chao, W. L. Guo and Y. T. Sung 2009 Application of Wood Vinegars Prepared from Branches and Tree Tops of Cryptomeria japonica at Different Collection Temperatures to Evaluate their Fungi Resistance for Moso Bamboo Material. Journal of the Faculty of Agriculture Kyushu University. Japan. 54(2): 457-462

Lin, H. C., Y. H. Huang, T. R. Tsai, C. W. Peng, G. S. Hwang and W. R. Kuo 2011 Investigation of Promoting Growth of Tomato Plug Seedlings from Moso Bamboo Charcoal Cultural Media with Bamboo Vinegar. J. Agric For. (NCYU), 8(2): 58-72

Lu, K. T., C. W. Kuo and C. T. Liu 2007 Inhibition Efficiency of a Mixed Solution of Bamboo Vinegar and Chitosan against Ralstonia solanacearum. Taiwan J For SCI., 22(3): 329 338

Maron, D. M. and B. N. Ames 1983 Revised methods for the Salmonella mutagenicity Test. Mutat Res., 113: 173-215

McCann, J., E. Choi, E. Yamasaki and B. N. Ames 1975 Detection of Carcinogens as Mutagens in the Salmonella/Microsome Test: Assay of 300 Chemicals. Proc Natl Acad Sci U S A., 72(12): 5135-5139

Namiki, M. 1990 Antioxidants/Antimutagens in Foods. Crit. Rev. Food Sci. Nutr. 29: 273-300

Nishimiya, K., T. Hata, Y. Imamura and S. Ishihara 1998 Analysis of Chemical Structure of Wood Charcoal by X-ray Photoelectron Spectroscopy. J. Wood Sci., 44: 56-61

Nomura, R. 2004. Healthy Effects of Bamboo Vinegar. Nobunkyou Publication, pp. 141-143

Sugimura, T., S. Sato, M. Nagao, T. Yahagi, T. Matsushima T. and Y. Seino $1976 \quad$ Overlapping of Carcinogens and Mutagens. Fundam Cancer Prev Proc Int Symp Princess Takamatsu Cancer Res Fund 6th 1975: pp. 191-215

Tsai, C. T., S. C. Wu, K. J. Lin, G. S. Hwang and H. C. Lin 2009 Evaluation of Antioxidation Activity and Resist Lipid Oxidation Effect with Moso Bamboo Vinegar Collection From Different Temperature. J. Agric For. (NCYU), 6(1): 66-83

Uchimura, T., H. Tanikai, and K. Hosoukawa 2000 Issues of Bamboo Charcoal and Bamboo Vinegar. Soumorisya Publication, pp. 138-168

Vasavada, M. N. and D. P. Cornforth 2006 Evaluation of Antioxidant Effects of Raisin Paste in Cooked Ground Beef, Pork, and Chicken. J Food Sci., 71(4): 242-246

Waleh, N. S., S. J. Rapport and K. E. Mortelmans 1982 Development of a toxicity test to be coupled to the Ames Salmonella assay and the method of construction of the required strains. Mutat Res., 97: 247-256

Yam, T. S., S. Shah and J. M. T. Hamilton-Miller 1997 Microbiology Activity of Whole and Fractionated Crude Extracts of Tea (Camellia sinensis), and of Tea Components. FEMS Microbiology Letters, 152: 169-174

Yatagai, M., G. Unrinin and T. Orira 1988 By-products of Wood Carbonization IV. Components of Wood Vinegar. Mokuzai Gakkaishi, 34: 184-188

Yatagai, M., M. Nishimoto, K. Hori, T. Ohira and A. Shibata 2002 Termiticidal Activity of Wood vinegar, its Components and Their Homologues. J. Wood Sci, 48: 338-342

Yen G. C., P. D. Duh, Y. L. Hung 2001 Contributions of Major Components to the Antimutagenic Effect of Hsian-Tsao (Mesona procumbens Hemsl.), Journal of Agricultural and Food Chemistry. 49: 5000-5004

Yoshie, L. 2004 Effects of Wood/Bamboo Vinegar on Cow Skin. Nobunkyou Publication, pp. 132-133 